\title{
Self-rated health and smoking among physicians and general population with higher education in Estonia: results from cross-sectional studies in 2002 and 2014
}

\author{
Kersti Pärna* (D), Inge Ringmets and Sävelin Siida
}

\begin{abstract}
Background: Poor self-rated health (SRH) and smoking have consistently been shown to be related to mortality. The aim of this study was to explore SRH and smoking among physicians and general population with higher education in Estonia in 2002 and 2014 and to analyse the association of SRH with smoking and sociodemographic factors.

Methods: This study was based on cross-sectional postal surveys among physicians and general population with higher education in Estonia $\mathrm{n}$ in 2002 and 2014. Calculation of age-standardized prevalence of SRH and current smoking with 95\% confidence intervals (Cl) was performed. Multivariate logistic regression analysis was used to measure association between SRH (at-least-good vs less-than good) and smoking status, study year, age group, ethnicity, and marital status. Fully adjusted odds ratios (OR) with 95\% CI were computed.

Results: Age-standardized prevalence of at-least-good SRH was 71.3 and $80.6 \%$ among male physicians, 68.4 and 83.1\% among female physicians, 45.4 and $67.4 \%$ among men with higher education, and 44.7 and $63.1 \%$ among women with higher education in 2002 and 2014, respectively. Age-standardized prevalence of current smoking was 26.0 and $15.6 \%$ among male physicians, 10.2 and 5.9\% among female physicians, 38.7 and $22.2 \%$ among men with higher education, and 20.9 and 16.4\% among women with higher education in 2002 and 2014, respectively. There was no significant gender difference in at-least-good SRH, but prevalence of current smoking was significantly higher among men in both study groups in 2002 and 2014. Compared to year 2002, odds to have at-least-good $\mathrm{SRH}$ was higher in $2014(\mathrm{OR}=1.64 ; 95 \% \mathrm{Cl} 1.16-2.31$ among male and $\mathrm{OR}=2.36 ; 95 \% \mathrm{Cl}$ 2.02-2.75 among female physicians, $\mathrm{OR}=1.49 ; 95 \% \mathrm{Cl} 1.07-2.07$ among men and $\mathrm{OR}=2.40 ; 95 \% \mathrm{Cl} 1.84-3.13$ ). Odds to have at-least-good SRH was significantly higher among non-smokers (except female physicians), in the youngest age group, and among Estonians.

Conclusions: This study gave an overview of differences in SRH and smoking between two target groups with higher education in two timepoints highlighting the importance of addressing smoking cessation counselling and health promotion campaigns in the population by different subgroups in Estonia.
\end{abstract}

Keywords: Self-rated health, Smoking, Physicians, General population with higher education, Sociodemographic factors, Estonia

\footnotetext{
* Correspondence: kersti.parna@ut.ee

Institute of Family Medicine and Public Health, University of Tartu, Ravila 19,
} 50411 Tartu, Estonia International License (http://creativecommons.org/licenses/by/4.0/), which permits unrestricted use, distribution, and reproduction in any medium, provided you give appropriate credit to the original author(s) and the source, provide a link to the Creative Commons license, and indicate if changes were made. The Creative Commons Public Domain Dedication waiver (http://creativecommons.org/publicdomain/zero/1.0/) applies to the data made available in this article, unless otherwise stated. 


\section{Background}

Poor self-rated health (SRH) and smoking have consistently been shown to be related to future mortality in different countries in Europe [1-3]. According to this, poorer SRH could be associated with smoking.

Poor SRH has decreased during the last decades among adult general population in European countries and has been more prevalent among lower socioeconomic class [4-6]. However, the number of published articles concerning SRH among physicians is much lower. In Lithuania, $70.5 \%$ of male and $58.9 \%$ of female physicians rated their health as at-least-good in 2006 [7]. In Norway $88.3 \%$ of male and $88.1 \%$ of female physicians, in Germany $62.9 \%$ of male and $64.1 \%$ of female physicians rated their health as at-least-good in 2008 [8].

Similarly to poor SRH, current tobacco smoking has decreased among adults in developed countries in Europe $[9,10]$ with higher prevalence among lower socioeconomic class in accordance to tobacco epidemic model [11]. Current tobacco smoking has also decreased among physicians in high income countries worldwide (e.g United States, Australia, Scandinavian countries) $[12,13]$ being comparable with the 'mature' smoking epidemic among physicians [14] with lower prevalence of smoking among physicians than among general population within the country. In Estonia there is studied SRH $[15,16]$ and smoking $[17,18]$ by socioeconomic position among general population and smoking among physicians [19], but there is no studies concerning SRH among physicians. Moreover, whether the association of $\mathrm{SRH}$ and smoking differ among physicians and general population with higher education, is not investigated in Estonia.

The aim of this study was to explore SRH and smoking among physicians and general population with higher education in Estonia in 2002 and 2014 and to analyse association of SRH with smoking and sociodemographic factors.

\section{Methods}

\section{Study population and design}

The present study was based on aggregated data of cross-sectional postal smoking surveys among physicians $[20,21]$ and health behaviour surveys among adult population in Estonia in 2002 and 2014 [22, 23].

\section{Surveys among physicians in 2002 and 2014}

The methods used in two cross-sectional postal surveys among physicians have been extensively described elsewhere $[20,21]$. In short, all practicing physicians who were permanent residents of Estonia were eligible for sampling in $2002(n=4140)$ and 2014 $(n=5666)$. In 2002, all practicing physicians were identified from the database of Estonian Health Insurance Fund and questionnaires were mailed to the workplace address of the physicians. In 2014, the sample of all practicing physicians was based on data from the Estonian Health Care Professionals Registry and questionnaires were mailed to the home address of physicians. To receive home addresses, data from the Estonian Health Care Professionals Registry were linked with the Population Registry in Estonia. The number of respondents was 2747 in 2002 and 2903 in 2014. The crude response rates were 66.3 , and $52.0 \%$, respectively. The corrected response rates (excluding the physicians who were unavailable, retired, had an incorrect address, had left Estonia or haddied) were $67.8 \%$ in 2002 and $53.1 \%$ in 2014. Similar self-administered questionnaires were used to collect information on SRH, smoking and sociodemographic factors in 2002 and 2014.

The target group of the present study were 25-64years-old physicians in $2002(n=2521)$ and in 2014 $(n=$ 2303) who answered to the questions concerning SRH and smoking status (Table 1).

\section{Surveys among general population in 2002 and 2014}

The study was based on data drawn from two crosssectional postal surveys of Health Behaviour among Estonian Adult Population conducted among 16-64-yearold adults in every second year since 1990. A random sample, stratified by age, gender and place of residence, of the Estonian population aged 16-64 was taken from the Population Registry. The methodology of survey of Health Behaviour among Estonian Adult Population is described in more detail elsewhere [22, 23]. In 2002 the initial sample consisted of 2000 adults, in 2014 the sample size was 5000 adults. The crude response rate of the inital sample was $66.9 \%$ in 2002 and $51.5 \%$ in 2014. The methodology and the questionnaires used in the surveys were harmonized to provide comparability between study years. Corrected response rate (exluding those, who did not live at the address provided, no letter box available, not living in Estonia, had died) was not available for 2002, but $53.5 \%$ in 2014 .

The target group of the present study was 25-64years-old general population with higher education in $2002(n=190)$ and in $2014(n=717)$ who answered to the questions concerning $\mathrm{SRH}$ and smoking status (Table 1).

\section{Study variables}

SRH was measured by a single question concerning selfassessment of the current state of health. Five options of responses were dichotomized to at-least-good (good, rather good) and less-than good (average, rather poor, poor) SRH.

Smoking status was determined by combining answers to several questions concerning daily (smoking at 
Table 1 Sample of 25-64-years old Estonian physicians and general population with higher education, 2002 and 2014

\begin{tabular}{|c|c|c|c|c|c|c|}
\hline \multirow{2}{*}{$\begin{array}{l}\text { Study } \\
\text { year }\end{array}$} & \multicolumn{3}{|c|}{ Physicians } & \multicolumn{3}{|c|}{ General population with higher education } \\
\hline & Men & Women & Total & Men & Women & Total \\
\hline 2002 & 415 & 2106 & 2521 & 62 & 128 & 190 \\
\hline 2014 & 403 & 1900 & 2303 & 245 & 472 & 717 \\
\hline Total & 818 & 4006 & 4824 & 307 & 600 & 907 \\
\hline
\end{tabular}

least one cigarette a day), occasional (smoking less than one cigarette a day, past and never smoking and was classified as current (smoking at least one cigarette or less than one cigarette a day), past (not currently smoking) and never (smoked less than 100 cigarettes during her/his life) smoking.

Study groups were 25-64-years-old physicians and general population with higher education in Estonia. Population with higher education was defined by the highest completed educational level which included at least 15 years of studies.

Study years were 2002 and 2014 for both study groups.

Age was measured in full years and analysed in four age groups: 25-34, 35-44, 45-54, 55-64.

Ethnicity referred to self-determined national identity and was analysed in two groups: Estonians and nonEstonian (mainly Russians).

Marital status was classified into three groups: married or cohabiting, single, separated or divorced or widowed.

\section{Statistical analysis}

As gender was associated with SRH and smoking, the results were analysed separately for males and females. The primary data analysis involved the calculation of age-standardized prevalence of SRH and current smoking using European standard population [24] with 95\% confidence intervals (CI). Multivariate logistic regression analysis was used to measure the association between SRH (at-least-good vs less-than good) and smoking status, study year, and sociodemographic factors (age group, ethnicity, and marital status) among physicians and general population with higher education. Fully adjusted odds ratios (OR) and the corresponding 95\% CI were computed.

The data was analysed using the statistical package Stata 12.1 [25].

\section{Results}

Age-standardized prevalence of at-least-good SRH among male physicians was $71.3 \%$ (95\% CI 66.9-75.6) in 2002 and $80.6 \%$ (95\% CI 77.1-84.2) in 2014 and among female physicians $68.4 \%$ (95\% CI 66.4-70.4) and $83.1 \%$ (95\% CI 81.5-84.7), respectively (Fig. 1). Age-standardized prevalence of at-least-good SRH among men with higher education was $45.4 \%$ (95\% CI 34.1-56.7) in 2002 and 67.4\% (95\% CI 61.4-73.3) in 2014, among women with higher education $44.7 \%(36.2-53.2)$ and $63.1 \%$ (95\% CI 58.7-67.5), respectively.

Age-standardized prevalence of current smoking among male physicians was $26.0 \%$ (95\% CI 21.4-30.5) in 2002 and $15.6 \%$ (95\% CI 12.0-19.2) in 2014 and among female physicians $10.2 \%$ (95\% CI 8.9-11.6) and 5.9\% (95\% CI 4.9-7.0), respectively (Fig. 2). Age-standardized prevalence of current smoking among men with higher education was $38.7 \%$ (95\% CI 27.0-50.5) in 2002 and $22.2 \%$ (95\% CI 17.0-27.4) in 2014 and among women with higher education $20.9 \%$ (95\% CI 13.6-28.3) and $16.4 \%$ (95\% CI 13.0-19.9), respectively.

In fully adjusted logistic regression model SRH was associated with smoking status (except among female physicians), study year, age, and ethnicity among physicians as well as among general population with higher education. No association was found between at-least-good SRH and marital status in both study groups.

Compared to currently smoking male physicians, odds to have at-least- good SRH was significantly higher among past and never smoking male physicians (Table 2). No association was found between SRH and smoking among female physicians. Compared to currently smoking men and

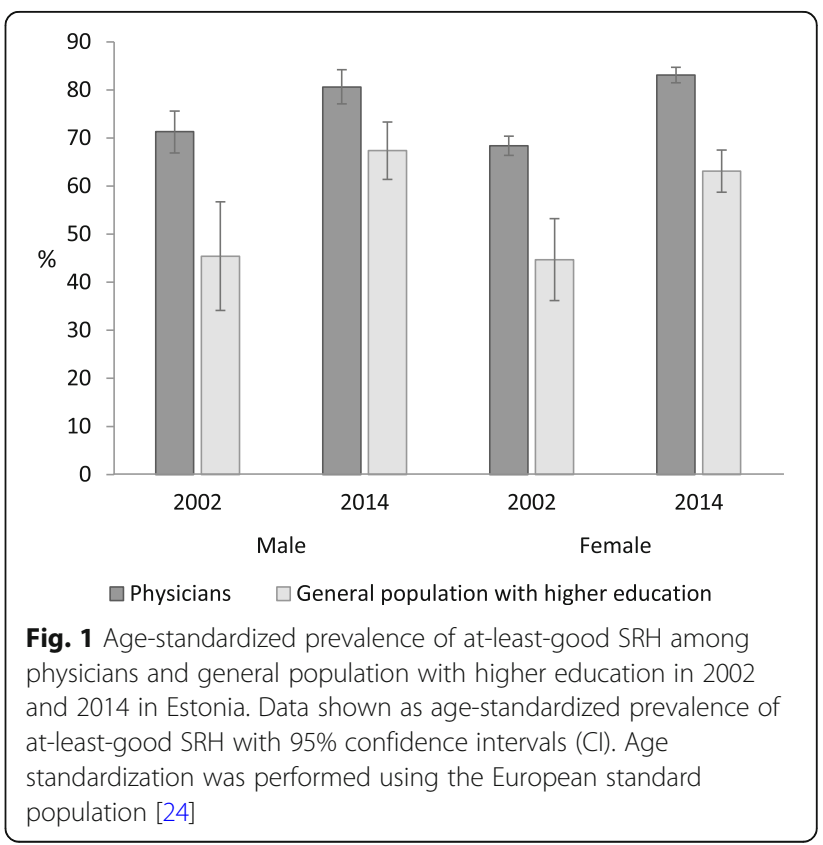




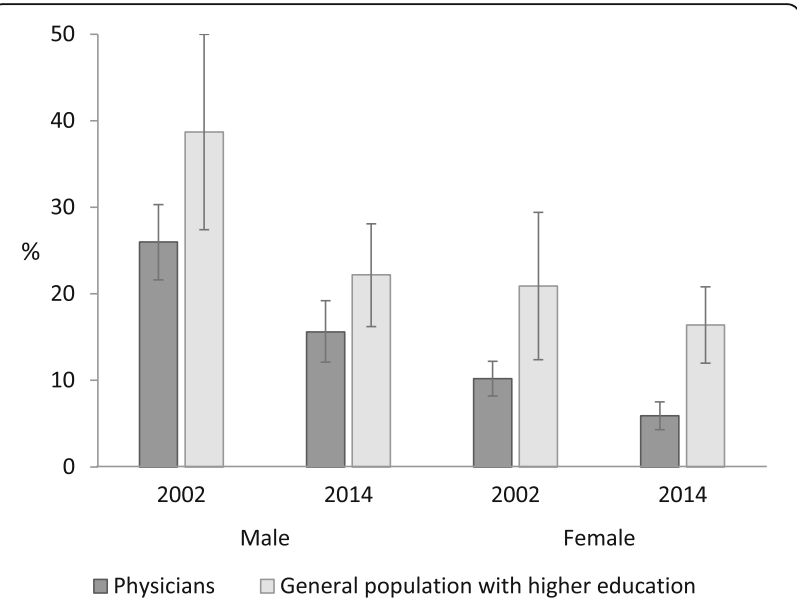

Fig. 2 Age-standardized prevalence of current smoking among physicians and general population with higher education in 2002 and 2014 in Estonia. Data shown as age-standardized prevalence of current smoking with 95\% confidence intervals (CI). Age

standardization was performed using the European standard population [24]

women with higher education, odds to have at-least-good SRH was significantly higher among never smoking men and women with higher education. Compared to study year 2002, odds to have at-least-good SRH was significanly higher among men and women in both study groups in 2014. Compared to the youngest age group, odds to have at-least-good SRH was significantly lower in older age groups in both study groups. Compared to non-Estonians, odds to have at-least-good SRH was significantly higher among Estonian men and women in both study groups.

\section{Discussion}

This study focused on SRH and smoking among physicians and general population with higher education in Estonia in 2002 and 2014, and analysed association of SRH with smoking and sociodemographic factors. The main findings from the study were, first, that compared to general population with higher education, prevalence of at-least-good SRH was higher and prevalence of current smoking lower among physicians. Second, compared to 2002, prevalence of at-least-good SRH was higher and prevalence of current smoking lower in 2014 in both study groups. Third, there was no significant gender difference in at-least-good SRH, but prevalence of current smoking was significantly higher among men in both study groups. Fourth, non-smokers (except female physicians), adults in the youngest age groups and Estonians considered their health better.

\section{Strengths and limitations}

The surveys of smoking among physicians and of health behaviour among adult general population present an outstanding opportunity to analyse SRH and smoking status among physicians and general population with higher education in 2002 and 2014 in Estonia because of the similar study design (postal cross-sectional surveys) and methodology (representative samples).

Before discussing the results some limitations of this study should be addressed. First, response rates in surveys among physicians as well as among general population was much lower in 2014 than in 2002, as is the case with postal surveys in most populations worldwide [26]. The non-respondents may have revealed different patterns of SRH and smoking status compared with those who returned the questionnaire. Thus, possible weaker participation of adults with lower SRH and smoking behaviour has to be considered [27, 28]. Second, smaller initial sample size in health behaviour survey among general population in 2002 might decrease power of detection of significant differences between study groups. Third, dichotomizing of SRH as at-least-good and lessthan-good was done assuming that respondents who rate their health as average are feeling not healthy. SRH refers to subjective health assessment and therefore there is not possible to draw a strict line between at-leastgood and less-than-good health. Such a categorization can affect the results as it is not definite to which group the 'average' is more similar to [29], however, a sensitivity analysis using different categorization for SRH in earlier study demonstrated similar associations with sociodemographic and -economic factors. Also, it has been reported that whether SRH was categorized to two groups or analyzed based on five point scale, the results were similar [30]. Fourth, self-reports of smoking tends to slightly underestimate the actual amount of smoking, especially among physicians as they know more about the devastating effects of smoking than the general population despite these caveats, several inferences can be drawn.

\section{$S R H$}

Compared to general population with higher education prevalence of at-least-good SRH was significantly higher among physicians of both genders in both study years in Estonia. This means that physicians' better knowledge concerning illnesses and increased prevalence of common mental disorders reported among physicians worldwide [31-33] were not associated with rating their health poorer. On the contrary, physicians rated their health better than general population with higher education. The age standardized prevalence of at-least-good SRH was significantly higher in 2014 than in 2002 among physicians as well as among general population with higher education in Estonia. While about two third to three fourth of physicians rated their health at-leastgood in 2002, then more than four fifth agreed with this choice in 2014 in Estonia. At the same time, in 2002, less 
Table 2 Odds ratios (OR) for SRH (at-least-good vs less-than-good) and 95\% confidence intervals (Cl) among physicians and general population with higher education by gender in 2002 and 2014

\begin{tabular}{|c|c|c|c|c|}
\hline \multirow[t]{3}{*}{ Characteristic } & \multicolumn{2}{|l|}{ Physicians } & \multicolumn{2}{|c|}{ Population with higher education } \\
\hline & \multicolumn{2}{|c|}{ Adjusted $^{\mathrm{a}}$ OR $(95 \% \mathrm{Cl})$} & \multicolumn{2}{|c|}{ Adjusted $^{\mathrm{a}}$ OR (95\% Cl) } \\
\hline & $\overline{M e n}$ & Women & $\overline{M e n}$ & Women \\
\hline \multicolumn{5}{|l|}{ Smoking status } \\
\hline Current & 1 & 1 & 1 & 1 \\
\hline Past & $1.85(1.20-2.85)$ & $1.07(0.80-1.45)$ & $1.20(0.90-1.59)$ & $1.32(0.99-1.78)$ \\
\hline Never & $2.39(1.58-3.60)$ & $1.04(0.80-1.34)$ & $1.65(1.21-2.24)$ & $1.39(1.08-1.79)$ \\
\hline \multicolumn{5}{|l|}{ Study year } \\
\hline 2002 & 1 & 1 & 1 & 1 \\
\hline 2014 & $1.64(1.16-2.31)$ & $2.36(2.02-2.75)$ & $1.49(1.07-2.07)$ & $2.40(1.84-3.13)$ \\
\hline \multicolumn{5}{|l|}{ Age group } \\
\hline $25-34$ & 1 & 1 & 1 & 1 \\
\hline $35-44$ & $0.65(0.35-1.22)$ & $0.49(0.37-0.66)$ & $0.51(0.37-0.71)$ & $0.65(0.48-0.87)$ \\
\hline $45-54$ & $0.36(0.20-0.67)$ & $0.28(0.21-0.38)$ & $0.27(0.19-0.38)$ & $0.35(0.26-0.47)$ \\
\hline $55-64$ & $0.19(0.10-0.35)$ & $0.16(0.12-0.21)$ & $0.15(0.10-0.22)$ & $0.16(0.12-0.22)$ \\
\hline \multicolumn{5}{|l|}{ Ethnicity } \\
\hline Non-Estonian & 1 & 1 & 1 & 1 \\
\hline Estonian & $1.50(1.02-2.21)$ & $1.96(1.62-2.37)$ & $1.66(1.25-2.22)$ & $2.44(1.94-3.06)$ \\
\hline \multicolumn{5}{|l|}{ Marital status } \\
\hline Married/cohabiting & 1 & 1 & 1 & 1 \\
\hline Single & $0.80(0.40-1.59)$ & $0.83(0.66-1.06)$ & $1.28(0.93-1.76)$ & $1.04(0.79-1.37)$ \\
\hline Divorced/widowed & $0.91(0.44-1.85)$ & $0.88(0.73-1.07)$ & $0.67(0.40-1.12)$ & $0.96(0.70-1.31)$ \\
\hline
\end{tabular}

${ }^{\mathrm{a}}$ Each OR was adjusted for all the other variables in the table

than half, but in 2014 about two third of general population with higher education rated their health at-least good in Estonia. Similar increase of prevalence of atleast-good health was described in earlier studies among general adult population in Estonia [15] and in Eastern European countries [34]. There was not found significant gender differences in prevalence of at-least good SRH among physicians and general population with higher education, which confirms the findings of earlier study in Estonia [15].

\section{Current smoking}

Compared to general population with higher education, prevalence of current smoking was significantly lower among physicians of both genders in both study years in Estonia. Previous study [19] in Estonia indicated that prevalence of smoking among physicians was much lower than that observed in the general population demonstrating that Estonia is comparable with 'mature' smoking epidemic among physicians [14]. The findings of current study indicated that physicians are far less likely to smoke than general population with higher education. The age standardized prevalence of current smoking was significantly lower in 2014 than in 2002 among male and female physians as well as among men and women in general population with higher education in Estonia. Similar decrease of prevalence of current smoking was described in earlier studies in Estonia [17] and in other developed European countries [35, 36]. The finding of this study that the prevalence of current smoking was significantly higher among men than women in both study groups in both study years is consistent with that seen in earlier studies in Estonia [1720]. Moreover, notably higher smoking prevalence among men is common in the former Soviet countries [37], meanwhile in the most Scandinavian and Western European countries gender difference in current smoking prevalence is much smaller [38].

\section{Association of SRH (at-least-good vs less-than-good) with smoking and sociodemographic factors}

Fully adjusted logistic regression model confirmed similar association of at-least-good SRH with nonsmoking (except female physicians), study year (2014), the youngest age group, and Estonian ethnicity in both study groups.

The fact, that at-least-good SRH was associated with study year 2014 was in accordance with higher prevalence of at-least good SRH in the year 2014 in this study. Association between at-least-good SRH and nonsmoking 
was found among male physicians and among men and women of general population with higher education. The fact, that SRH was not associated with smoking status among female physicians could be explained with not intensive smoking among them. Compared to the adults in the youngest age group adults in older age groups had lower odds to assess their health as at-leastgood in Estonia. This finding was in accordance with the results from previous studies [16, 34]. Compared to nonEstonian men and women, odds to have at-least-good SRH was significantly higher among Estonians in both study groups. In earlier studies describing data from Estonia, controversial results were reported. Some studies showed that compared to non-Estonians, Estonians were more likely to rate their health as good [39, 40], but some studies found associations between SRH and nationality only among women $[15,30]$.

\section{Conclusions}

This paper provided a new information concerning SRH and smoking among physicians as well as among general population with higher education in Estonia in 2002 and 2014. Compared to the general population with higher education, prevalence of at-least-good SRH was higher and of current smoking lower among physicians in both study years. Compared to 2002, prevalence of at-leastgood SRH was higher and prevalence of current smoking lower in both study groups in 2014. There was no gender differences in prevalenc of at-least-good SRH, but prevalence of current smoking was higher among men compared to women in both study groups. Non-smokers (except female physicians), adults in the youngest age group and Estonians considered their health better in both study groups.

In conclusion, this study gave an overview of SRH and smoking in two target groups with higher education in two timepoints highlighting the importance of addressing smoking cessation counselling and health promotion campaigns in the population in Estonia by different subgroups.

\section{Acknowledgements \\ The authors thank the entire team who has been involved in designing and conducting the survey among physicians in 2014 in Estonia. The authors thank the National Institute for Health Development in Estonia for permission to use the data from the survey of Health Behaviour among Estonian Adult Population.}

\section{Authors' contributions}

KP made a substantial contribution to the conception and the design of the study and was a major contributor in writing the manuscript. IR developed the best reasoned supplementary data analysis option for the article and conducted additional data analysis. SS made the bibliographic analysis and did the original data analysis. All authors read and approved the final manuscript.

\section{Funding}

This work was supported by the Estonian Research Council (grant numbers PUT-299 and IUT34-17).

\section{Availability of data and materials}

The datasets of physicians used and analysed during the current study are available from the corresponding author on reasonable request. The datasets of general population used and analysed during the current study are available from the responsible coordinators of these surveys in Estonia on reasonable request.

\section{Ethics approval and consent to participate}

The surveys in 2002 and 2014 among physicians were approved by the Research Ethics Committee of the University of Tartu (decisions no. 87/1 and 235/T-12, respectively). The surveys among general population (Health Behaviour among Adult Population in Estonia) in 2002 and 2014 were approved by the Tallinn Medical Research Committee.

The questionnaires in both surveys were accompanied by a separate survey information sheet. It provided detailed description of the survey methodology including its ethical aspects (autonomy, data handling etc). Survey participation was therefore considered as informed consent. This is quite common practice for large-scale population surveys as separate consent forms would affect both the response rates (additional response burden) and survey costs (i.e. postal fees), and was approved by local ethics commitee for both surveys.

\section{Consent for publication}

Not applicable.

\section{Competing interests}

The authors declare that they have no competing interests.

Received: 17 May 2019 Accepted: 4 November 2019

Published online: 25 November 2019

References

1. Hillen T, Schaub R, Hiestermann A, Kirschner W, Robra BP. Self rating of health is associated with stressful life events, social support and residency in east and West Berlin shortly after the fall of the wall. J Epidemiol Community Health. 2000;54:575-80.

2. Bopp M, Braun J, Gutzwiller F, Faeh D. Health risk or resource? Gradual and independent association between self-rated health and mortality persists over 30 years. PLoS One. 2012;7:e30795.

3. Reile R, Stickley A, Leinsalu M. Large variation in predictors of mortality by levels of self-rated health: results from an 18-year follow-up study. Public Health. 2019;145:59-66.

4. Molarius A, Berglund K, Eriksson C, Lambe M, Nordstrom E, Eriksson HG, et al. Socioeconomic conditions, lifestyle factors, and self-rated health among men and women in Sweden. Eur J Pub Health. 2007;17:125-33.

5. Kunst AE, Bos V, Lahelma E, Bartley M, Lissau I, Regidor E, et al. Trends in socioeconomic inequalities in self-assessed health in 10 European countries. Int J Epidemiol. 2005;34:295-305.

6. Nicholson A, Bobak M, Murphy M, Rose R, Marmot M. Socio-economic influences on self-rated health in Russian men and women - a life course approach. Soc Sci Med. 2005;61:2345-54.

7. Baubinas A, Gurevicius R, Jankauskiene K, Salyga J, Kairys J, Jurkstiene V, et al. Self-rated health among physicians. Medicina. 2009;45:557-64.

8. Rosta J, Aasland OG. Work hours and self-rated health of hospital doctors in Norway and Germany. A comparative study on national samples. BMC Health Serv Res. 2011;11:40.

9. Giskes K, Kunst AE, Benach J, Borrell C, Costa G, Dahl E, et al. Trends in smoking behaviour between 1985 and 2000 in nine European countries by education. J Epidemiol Community Health. 2005;59:395-401.

10. World Health Organization (WHO). European health for all database (HFADB). https://gateway.euro.who.int/en/hfa-explorer/. Accessed 15 Mar 2019.

11. Lopez AD, Collishaw NE, Piha T. A descriptive model of the cigarette epidemic in developed countries. Tob Control. 1994;3:242-7.

12. Smith DR, Leggat PA. An international review of tobacco smoking in the medical profession: 1974-2004. BMC Public Health. 2007;7:115. 
13. Sarna L, Bialous SA, Nandy K, Antonio ALM, Yang Q. Changes in smoking prevalences among health care professionals from 2003 to 2010-2011. JAMA. 2014;311:197-9.

14. Davis RM. When doctors smoke. Tob Control 1993. 1993:2:187-8.

15. Põld M, Pärna K, Ringmets I. Trends in self-rated health and association with socioeconomic position in Estonia: data from cross-sectional studies in 1996-2014. Int J Equity Health. 2016;8:200.

16. Pärna K, Ringmets I. Comparison of socioeconomic differences in selfperceived health in Estonia and Finland. Scand J Public Health. 2010;38: 129-34.

17. Pärna K, Pürjer M-L, Ringmets I, Tekkel M. Educational differences in cigarette smoking among adult population in Estonia, 1990-2010: does the trend fit the model of tobacco epidemic? BMC Public Health. 2014;14:709.

18. Pärna K, Rahu K, Rahu M. Patterns of smoking in Estonia. Addiction. 2002;97: 871-6.

19. Pärna K, Põld M, Ringmets I. Trends in smoking behaviour among Estonian physicians in 1982-2014. BMC Public Health. 2017;18:55.

20. Pärna K, Rahu K, Barengo NC, Rahu M, Sandstrom PH, Jormanainen VJ, et al. Comparison of knowledge, attitudes and behaviour regarding smoking among Estonian and Finnish physicians. Soz Praventivmed. 2005:50(6):378-88.

21. Põld M, Pärna K. Smoking prevalence and attitudes towards smoking among Estonian physicians: results from cross-sectional studies in 2002 and 2014. BMJ Open. 2017;7:e017197.

22. Kasmel A, Lipand A, Markina A. Eesti täiskasvanud elanikkonna tervisekäitumise uuring, kevad 2002. [Health Behaviour among Estonian Adult Population, Spring 2002]. Tallinn: Estonian Centre for health education and promotion; 2003.

23. Tekkel $M$, Veideman $T$. Eesti täiskasvanud rahvastiku tervisekäitumise uuring, 2014. [Health Behavior among Estonian Adult Population, 2014]. Tallinn: Institute for Health Development; 2015.

24. Ahmad OP, Boschi-Pinto C, Lopez AD, Murray CJL, Lozano R, Inoue M. Age standardization of rates: a new WHO standard, GPE Discussion Paper Series: No. 31. Geneva: World Health Organization; 2001

25. StataCorp. Stata Statistical Software: Release 12. College Station: StataCorp LP; 2011.

26. Cook JV, Dickinson HO, Eccles MP. Response rates in postal surveys of healthcare professionals between 1996 and 2005: an observational study. BMC Health Serv Res. 2009;9:160.

27. Wong SL, Shields M, Leatherdale S, Malaison E, Hammond D. Assessment of validity of self-reported smoking status. Health Rep. 2012;23:47-53.

28. Helasoja V, Prättälä R, Dregval L, Pudule I, Kasmel A. Late response and item nonresponse in the Finbalt health monitor survey. Eur J Pub Health. 2002; 12:117-23.

29. Reile R, Leinsalu M. Differentiating positive and negative self-rated health: results from a cross-sectional study in Estonia. Int J Public Health. 2013;58: 555-64

30. Reile R, Helakorpi S, Klumbiene J, Tekkel M, Leinsalu M. The recent economic recession and self-rated health in Estonia, Lithuania and Finland: a comparative cross-sectional study in 2004-2010. J Epidemiol Community Health. 2014;68:1072-9.

31. Clarke D, Singh R. Life events, stress appraisals, and hospital doctors' mental health. N Z Medical J. 2004:117:U1121.

32. Yilmaz A. Burnout, job satisfaction, and anxiety-depression among family physicians: a cross-sectional study. J Fam Med Prim Care. 2018;7:952-6.

33. Paiva CE, Martins BP, Paiva BSR. Doctor, are you healthy? A cross-sectional investigation of oncologist burnout, depression, and anxiety and an investigation of their associated factors. BMC Cancer. 2018;18:1044.

34. Hu Y, van Lenthe FJ, Borsboom GJ, Looman CW, Bopp M, Burström B, et al. Trends in socioeconomic inequalities in self-assessed health in 17 European countries between 1990 and 2010. J Epidemiol Community Health. 2016;70: 644-52.

35. Midlöv P, Calling S, Sundquist J, Sundquist K, Johansson SE. The longitudinal age and birth cohort trends of smoking in Sweden: a 24-year follow-up study. Int J Public Health. 2014;59:243-50.

36. Marques-Vidal P, Cerveira J, Paccaud F, Cornuz J. Smoking trends in Switzerland, 1992-2007: a time for optimism? J Epidemiol Community Health. 2011;65:281-6.

37. Roberts B, Gilmore A, Stickley A, Rotman D, Prohoda V, Haerpfer C, et al. Changes in smoking prevalence in 8 countries of the former Soviet Union between 2001 and 2010. Am J Public Health. 2012;102:1320-8.
38. Zatonski W, Przewozniak K, Sulkowska U, West R, Wojtyla A. Tobacco smoking in countries of the European Union. Ann Agric Environ Med. 2012; 19:181-92.

39. Leinsalu M. Social variation in self-rated health in Estonia: a cross-sectional study. Soc Sci Med. 2002;55:847-61.

40. Sildever Ü, Pärna K, Ringmets I. Tervise enesehinnangu sotsiaalmajanduslikud erinevused Eestis: Euroopa sotsiaaluuring 2004. [Socioeconomic differences in self-perceived health in Estonia: European social survey 2004]. Eesti Arst. 2008;87:13-8.

\section{Publisher's Note}

Springer Nature remains neutral with regard to jurisdictional claims in published maps and institutional affiliations.
Ready to submit your research? Choose BMC and benefit from:

- fast, convenient online submission

- thorough peer review by experienced researchers in your field

- rapid publication on acceptance

- support for research data, including large and complex data types

- gold Open Access which fosters wider collaboration and increased citations

- maximum visibility for your research: over $100 \mathrm{M}$ website views per year

At BMC, research is always in progress.

Learn more biomedcentral.com/submissions 